\title{
Night-time enhanced atmospheric ion concentrations in the marine boundary layer
}

\author{
N. Kalivitis ${ }^{1,3,4}$, I. Stavroulas ${ }^{1}$, A. Bougiatioti ${ }^{1}$, G. Kouvarakis ${ }^{1}$, S. Gagnée ${ }^{2,5,6}$, H. E. Manninen ${ }^{2}$, M. Kulmala ${ }^{2}$, and \\ N. Mihalopoulos 1 \\ ${ }^{1}$ Environmental Chemical Processes Laboratory, Department of Chemistry, University of Crete, 71003, Heraklion, Greece \\ ${ }^{2}$ Department of Physics, P.O. Box 64, 00014 University of Helsinki, Finland \\ ${ }^{3}$ Department of Physical Geography and Quaternary Geology, Stockholm University, 10691 Stockholm, Sweden \\ ${ }^{4}$ Navarino Environmental Observatory (NEO), Messinia, Greece \\ ${ }^{5}$ Department of Physics and Atmospheric Science, Dalhousie University, Halifax, B3H 3J5, Canada \\ ${ }^{6}$ Environment Canada, Toronto, M3H 5T4, Canada
}

Correspondence to: N. Mihalopoulos (mihalo@chemistry.uoc.gr), N. Kalivitis (nkalivitis@chemistry.uoc.gr)

Received: 7 February 2011 - Published in Atmos. Chem. Phys. Discuss.: 15 April 2011

Revised: 12 March 2012 - Accepted: 23 March 2012 - Published: 17 April 2012

\begin{abstract}
Measurements of atmospheric ions in the size range $0.8-42 \mathrm{~nm}$ were conducted at the environmental research station of the University of Crete at Finokalia from April 2008 to April 2009 in the frame of the EUCAARI project. Both positive and negative atmospheric ions were found to have a clear annual cycle, with minimum concentrations in summer. Their concentrations were found to vary with the prevailing meteorology and the abundance of aerosol particles in the atmosphere. High concentrations of ions were observed during new particle formation events. There were 53 nucleation events recorded. It was found that under certain atmospheric conditions enhanced ion concentrations can be observed during night. Overall, 39 night-time events were observed, all of them observed for the negatively charged particles while only 21 were observed for the positively charged particles. Night-time enhanced ion concentrations were more frequent during spring and autumn and no such events were recorded from July to September. A strong anti-correlation was found between air ion concentrations, especially at cluster sizes $(1.25-1.66 \mathrm{~nm})$, and condensation and coagulation sinks. Enhanced ion concentrations at night were found to be more frequent when air masses had traveled over the island of Crete, indicating possible association with local biogenic sources.
\end{abstract}

\section{Introduction}

Atmospheric ions (charged molecular clusters or particles) have been measured at different sites around the world (Kulmala and Tammet, 2007). The main sources of air ions are radon decay and cosmic radiation (Israël, 1970; Bazilevskaya et al., 2008). Although atmospheric ions account only for a small fraction of the ambient particle population near the earth's surface, they can produce significant amounts of ion-clusters that could, later on, grow to become atmospheric aerosols. Several studies have shown that ion-induced nucleation does occur in the atmosphere (e.g. Virkkula et al., 2007a; Hirsikko et al., 2007; Laakso et al., 2004; Vana et al., 2008; Gagné et al., 2008; Manninen et al., 2010). It has to be pointed out that ion induced nucleation is not directly related to ion pair production but it is related to ion concentration and therefore the study of atmospheric ion concentration is important especially for the cluster sizes. Hirsikko et al. (2007) found that the Air Ion Spectrometer (AIS) could detect particle formation events that were suppressed, due to low concentrations of condensing vapours or high condensation and coagulational sink by pre-existing aerosol particles, before the DMPS (detection limit $3 \mathrm{~nm}$ ) detected any particles. Thus, such studies of ion mobility distributions could provide valuable insights into mechanisms of particle formation and growth. 
So far, there exist several observations of air ions in the marine or coastal environment (e.g. Eichmeier and von Berckheim, 1979; Wilding and Harrison, 2005; Vana et al., 2008). A review of observations of ions in marine and coastal areas can be found in Hirsikko et al. (2011). For the Mediterranean area very few observations exist (Retalis et al., 1977, 2009) and they refer to the urban environment of Athens. During the EUCAARI project (European Integrated Project on Aerosol Cloud Climate Air Quality Interactions; Kulmala et al., 2009; Kerminen et al., 2010) air ions were monitored continuously for one year at the remote coastal site of Finokalia, Crete (Manninen et al., 2010).

In this work we present atmospheric ion measurements at the marine environment of the eastern Mediterranean and explore their variability with respect to various atmospheric parameters. It has already been shown that air ion concentrations are strongly dependent on the prevailing meteorological conditions (e.g. Vana et al., 2008; Virkkula et al., 2007a). Special focus is given to night-time ion behavior as, despite the increasingly active research on air ions during the last decade, very few studies on the evolution of small ion concentrations during night-time have been published to date.

Junninen et al. (2008) reported increases in both concentration and mean size of small ions in a boreal forest environment in Hyytiälä during night-time. Furthermore, Siingh et al. (2005) observed higher night-time than day-time ion concentrations in fair weather conditions during their cruise on the Arabian Sea. Junninen et al. (2008) reported that the observed increases were most frequent on nights following a new particle formation event day, suggesting a possible contribution from the same vapours in both day-time and nighttime growth. Furthermore, Lehtipalo et al. (2011) showed that the night-time events in Hyytiälä are seen equally frequently for neutral particles, and that the night-time concentrations of sub- $3 \mathrm{~nm}$ particles and ions have a clear connection to oxidized organic molecules. Another aim of this study is to explore the night-time ion behavior in a completely different environment (coastal Mediterranean area) by checking also for a link with day-time nucleation events.

\section{Experimental}

\subsection{Site description}

The measurements took place at the environmental research station of the University of Crete at Finokalia, Lassithiou, Greece $\left(35^{\circ} 20^{\prime} \mathrm{N}, 25^{\circ} 40^{\prime} \mathrm{E}, 250 \mathrm{~m}\right.$ a.s.l.) during the period April 2008-April 2009 in the frame of the EUCAARI project. The Finokalia station is a remote coastal site in the northeast part of the island of Crete situated in the middle of the Eastern Mediterranean. The station is situated $70 \mathrm{~km}$ northeast of Heraklion, which is the major urban area of the island with approximately 170000 inhabitants. A detailed description of the site and the prevailing meteorology in the area can be found in Mihalopoulos et al. (1997). The site is considered representative for the MBL (Marine Boundary Layer) conditions of the Eastern Mediterranean (Lelieveld et al., 2002).

\subsection{Instrumentation}

The mobility distribution of air ions was measured using an AIS as part of the EUCAARI project (Manninen et al., 2010). The mobility diameters recorded were in the range $0.8-42 \mathrm{~nm}$ with a time resolution of five minutes. The number counting threshold was approximately $10 \mathrm{~cm}^{-3}$ and the uncertainties of the AIS measurements were $\sim 10 \%$ for negative and positive ion concentrations and $\sim 0.5 \mathrm{~nm}$ in size based on laboratory calibrations (Asmi at al., 2009; Gagné et al., 2011). Details on operational principles of the AIS can be found in Mirme et al. (2007). The AIS used at Finokalia took part in a calibration and inter-comparison workshop before and after the EUCAARI field measurements (see Asmi et al., 2009; Gagné et al., 2011). Mobility, concentration and flow calibrations were performed and it was concluded that the AISs have a good performance for mobility and concentration measurements. The AISs detected similar concentrations as reference instruments at concentrations corresponding to particle formation events, whereas the mobilities were slightly overestimated. The median ratio of negative ion concentration to reference concentration for all studied ion spectrometers varied from $1.0 \pm 0.1$ to $1.5 \pm 0.2$ depending on calibration set-up. Same numbers for positive ion concentration ratios varied from $0.9 \pm 0.2$ to $1.0 \pm 0.2$. Furthermore, it has been shown that the ion spectrometer compares well with other aerosol instruments also in field conditions (Kulmala et al., 2007; Manninen et al., 2009). Measurements of a new particle formation event by AISs, NAISs and reference instruments were compared to each other and all instruments gave similar results (Gagné et al., 2011). The diameter of the AIS inlet tube was $35 \mathrm{~mm}$ and the sample flow rate was $60 \mathrm{lpm}$. The diffusional losses inside the inlet tubing can be considered as minor. Nevertheless, the losses in the AIS sampling lines have been taken into account in the data inversion.

In order to evaluate the atmospheric conditions governing the air ion concentration levels at Finokalia, additional data obtained from the station's routine measurements were used. The particle number size distribution of ambient aerosol (dried at $\mathrm{RH}<40 \%$ ) was measured with a custombuilt Scanning Mobility Particle Sizer (SMPS) (Birmili et al., 1999) in the size range $8-900 \mathrm{~nm}$. SMPS data were used to calculate Condensation and Coagulation sink (CS and CoagS, respectively) according to Kulmala et al. (2001). Ozone concentrations were measured using a Thermo Electron 49C ozone monitor. Calibration and maintenance procedures can be found in Kouvarakis et al. (2000). Black Carbon (BC) concentration in the atmosphere was determined using a Magee Scientific Aethalometer. The data were corrected only for filter loading artifacts using the adjustment 


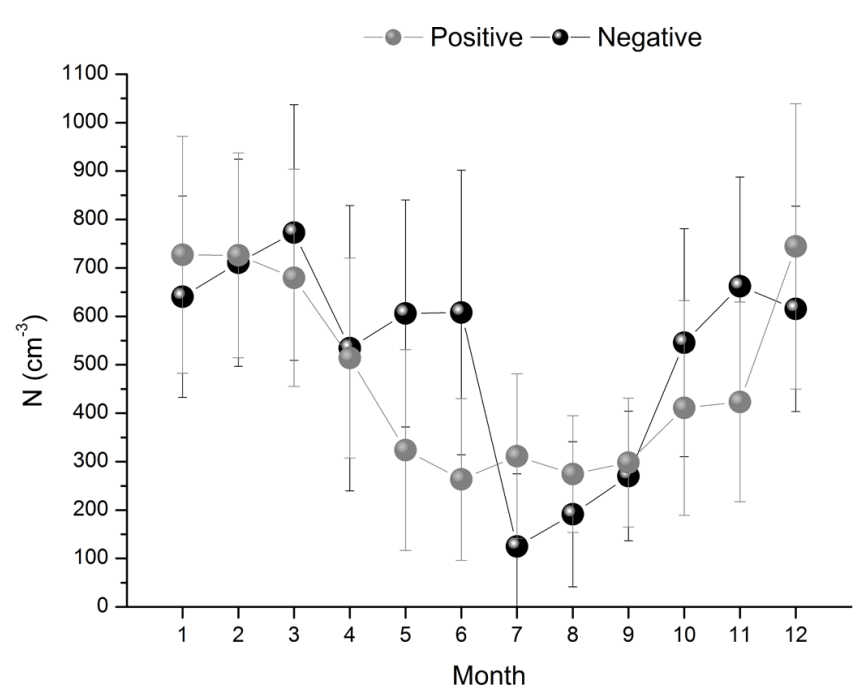

Fig. 1. Annual variability of atmospheric ion concentrations in the size range $0.8-42 \mathrm{~nm}$ (monthly averages and standard deviation) at Finokalia, Crete.

procedures of Virkkula et al. (2007b). Although the detection limit of the instrument is $0.1 \mu \mathrm{g} \mathrm{m}^{-3}$ and multiple scattering effects have not been taken into account, low $\mathrm{BC}$ values are presented that should be taken into account as an indication of clean air mass conditions and not as absolute $\mathrm{BC}$ values. Meteorological parameters were recorded by the automatic weather station installed at Finokalia at $2 \mathrm{~m}$ above ground level (a.g.l.). The time resolution for all of the measurements was $5 \mathrm{~min}$. The inlet of the AIS was at $\sim 1.5 \mathrm{~m}$ a.g.l. and situated at $15 \mathrm{~m}$ southeast of the weather station.

\section{Results and discussion}

\subsection{Air ion features at Finokalia}

Atmospheric ions were measured continuously for one year with the aim to detect annual trends and seasonal variations of their number concentration, and its dependence on the prevailing atmospheric conditions and composition at Finokalia. The average monthly number concentrations of charged particles were calculated so that the annual variability can be explored. Number concentrations of atmospheric ion with size $0.8-42 \mathrm{~nm}$ were found to have a clear annual cycle (Fig. 1). Minimum levels were observed during summer both for negative and positive particles. Although the main trend was common to both polarities, somewhat different features were observed with regard to maximum values. Positive ions presented maximum concentrations during winter. However, negatively charged ion number concentrations were found to present a maximum in March and presented two secondary maxima in June and in November. Throughout the measuring period negative ions had slightly higher values than the positive: $521.6 \pm 295.7 \mathrm{~cm}^{-3}$ against $473.2 \pm 284.1 \mathrm{~cm}^{-3}$ even if the concentration of positive ions was higher than that of the negative for almost half of the year on a monthly basis. The diurnal cycle of atmospheric ions is similar for both polarities as can be seen in Fig. 2a. Minimum concentrations are observed during day-time, while maximum during the night. Average daily cycles for CS and CoagS for particles of 2 $\mathrm{nm}$ and for the period under study were calculated and are presented in Fig. 2b. Ion concentrations and CS and CoagS have the opposite diurnal cycles. During the night when high ion concentrations were observed CS and CoagS had lower values and vice versa. The rapid drop of ion concentrations after 05:00 observed for both polarities coincides with the increase observed for the sinks. A similar trend is observed for $\mathrm{BC}$ concentration, indicative that a depletion of atmospheric aerosols is taking place during the night, potentially because of deposition processes. This can be observed in Fig. 2d, where diurnal cycles of ozone and BC are presented. CS and CoagS diurnal cycles closely follow the ozone ones as well. This can be attributed to the initiation of photochemistry in the atmosphere and the production of condensable species that leads to the growth of atmospheric aerosols to larger diameters. Additionally, it has already been shown for Finokalia that, during summer, the condensation of sulfuric acid vapours on small aerosols can result effectively to their complete depletion (Kalivitis et al., 2008).

Air ion concentrations have been found to have a strong dependence on the meteorological conditions, as it has been reported in earlier work as well (Vana et al., 2008; Virkkula et al., 2007a). The average diurnal variations for ambient temperature $(T)$, relative humidity $(\mathrm{RH})$ and wind velocity $\left(W_{s}\right)$ were calculated as well, to investigate if and how much the prevailing meteorological conditions can affect ion concentrations and are presented in Fig. 2c. Since average diurnal patterns for meteorological parameters are subject to great seasonal variations, no clear dependence of ion concentrations on meteorology could be observed, except for a similar diurnal pattern for $T$. To explore the potential effect of prevailing meteorology on ion concentrations it was considered necessary to investigate the dependence on the totality of the collected data. Figure $3 \mathrm{a}-\mathrm{d}$ present the frequency distribution diagrams and their corresponding histograms of ions versus $T$ and $W_{s}$. Only positively charged ions are presented, as the negative ions display similar behavior. The chromatic scale represents the data density in terms of points per area ratio. Ion concentrations clearly decrease with increasing temperature and at temperatures greater than $25^{\circ} \mathrm{C}$, typically observed on Crete during summer, ion concentrations were limited and hardly any episodes of enhanced values were observed (Fig. 3a). Ion concentrations were found to be anti-correlated with $T$ and this dependence was the most statistically significant, $R^{2}$ was 0.31 for positive ions and 0.19 for negative ( $n \sim 80000, a=0.05$ for both cases). When it concerned RH, no clear dependence was found (not shown). Regarding wind speed it is clear that the highest ion levels occur under low wind speed, indicative of stagnant 

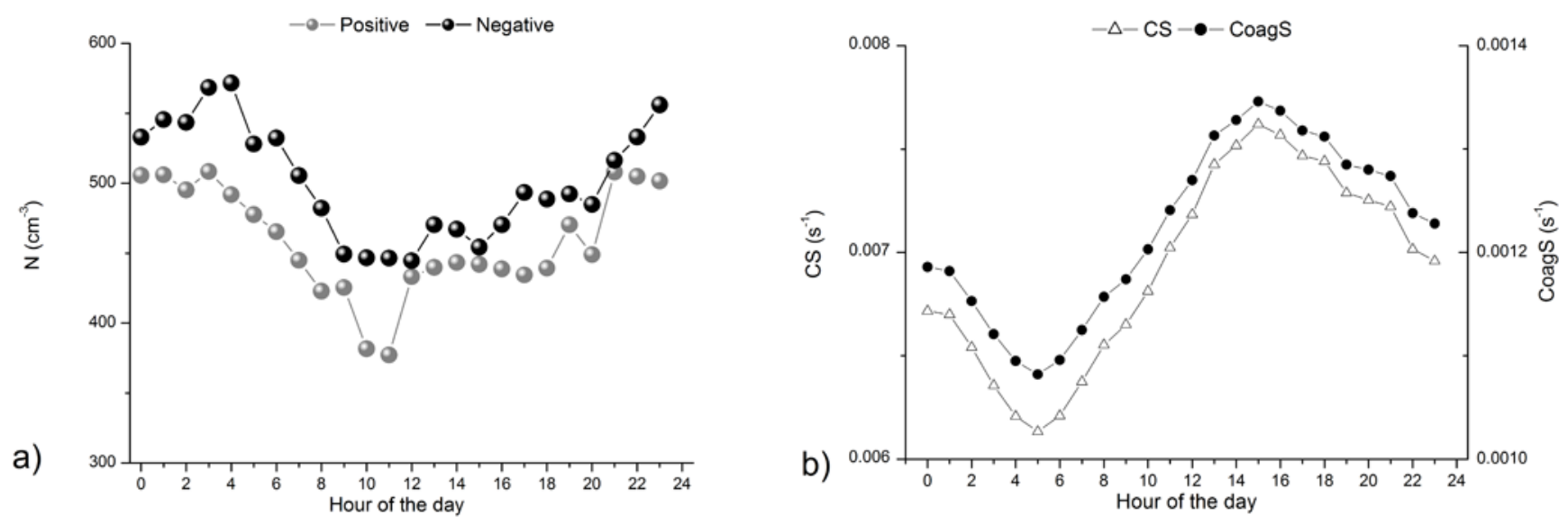

c)
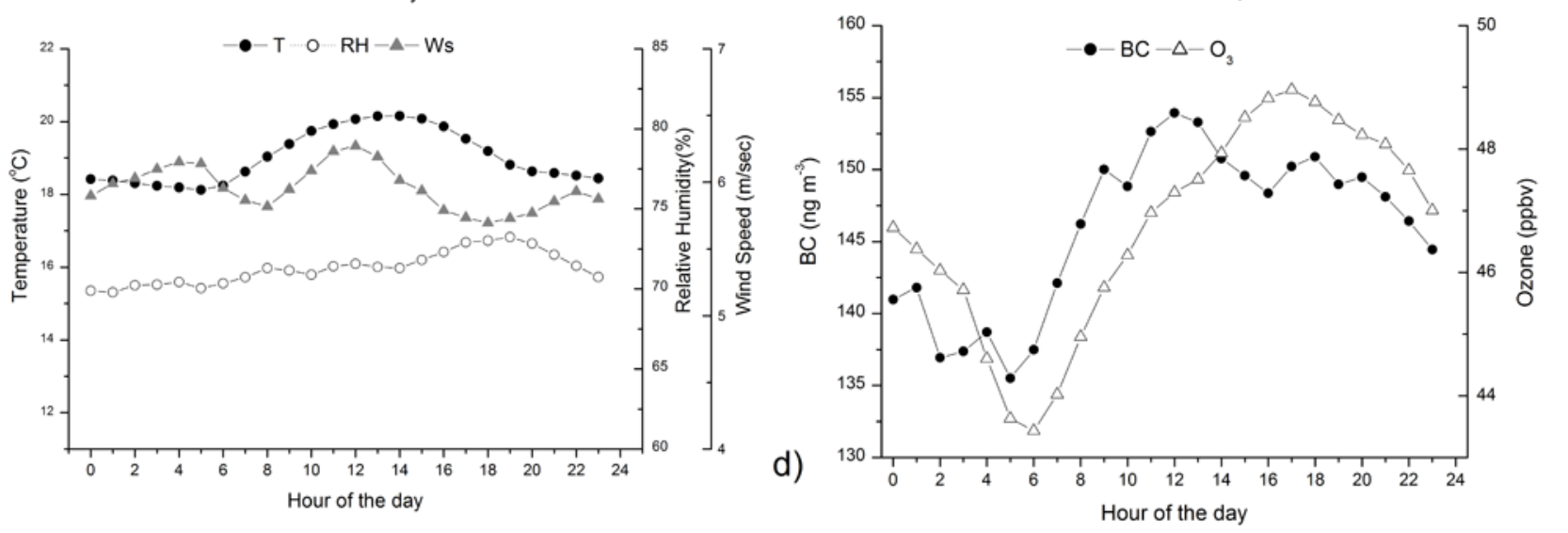

Fig. 2. Median diurnal cycles (hourly averages), at Finokalia of (a) Atmospheric ion concentrations in the size range $0.8-42 \mathrm{~nm}$ (b) CS and CoagS, (c) $T$, RH and $W_{S}$ and (d) BC and ozone.
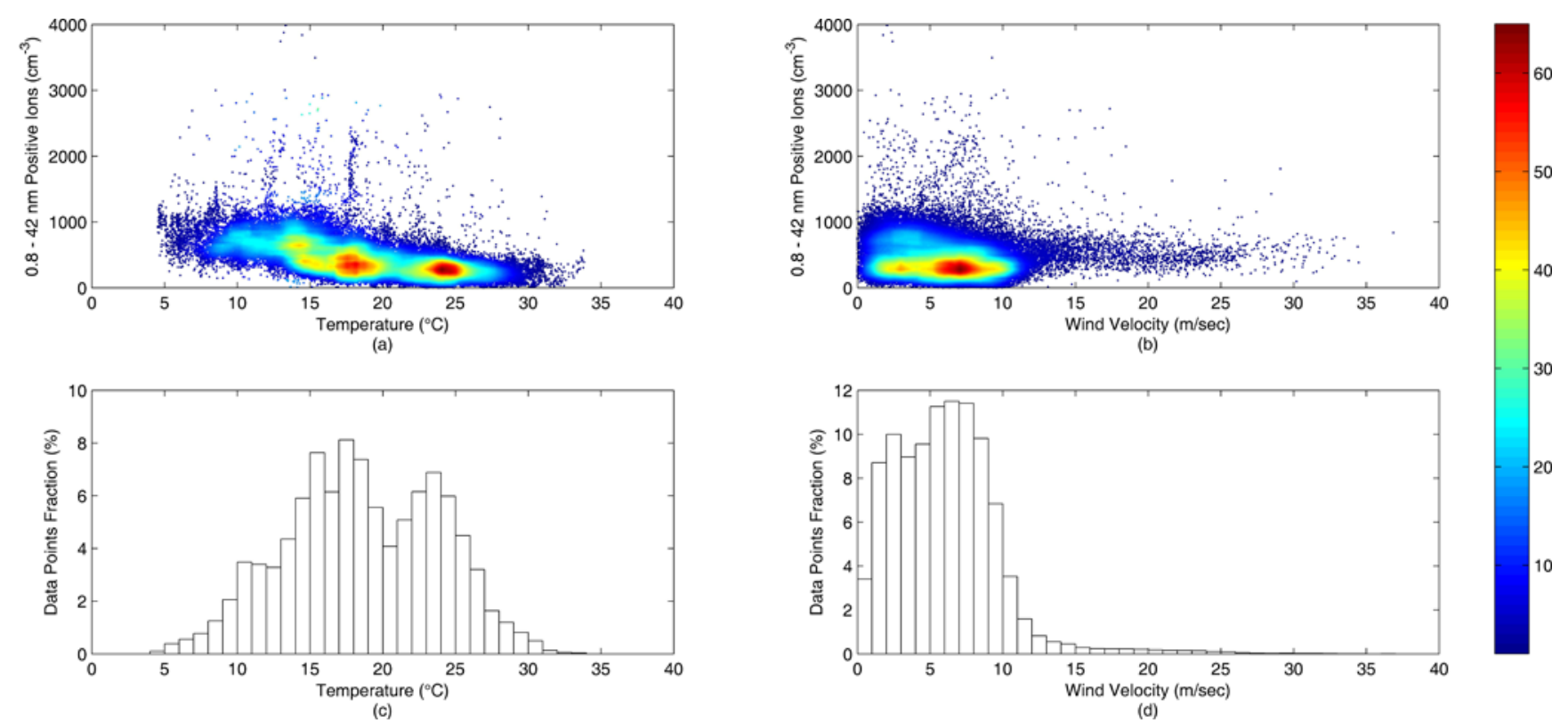

Fig. 3. Variability of positively charged atmospheric ion concentrations in the size range $0.8-42$ nm depending on temperature and wind velocity $(\mathbf{a}, \mathbf{b})$, and data fraction for positive ions with respect to temperature and wind velocity (c, d). 

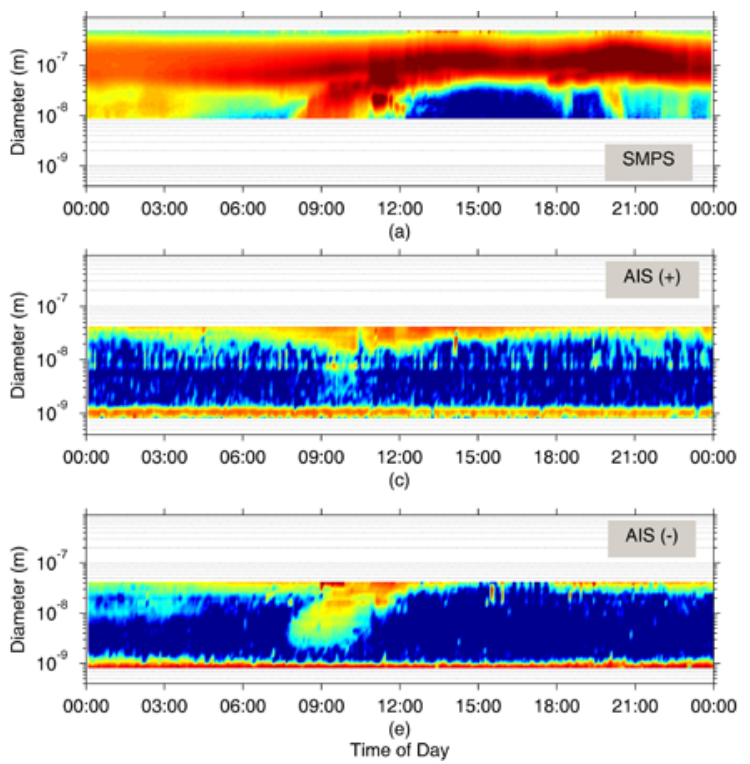

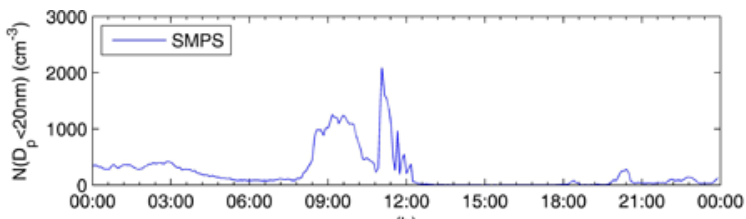

(b)
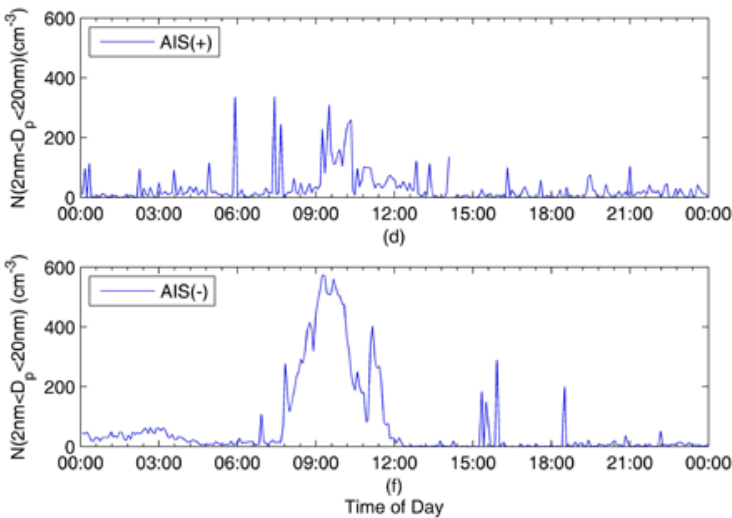

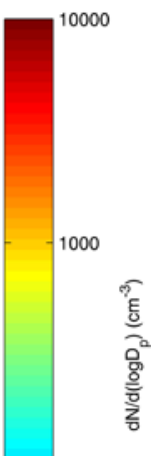

Fig. 4. New particle formation event recorded at Finokalia on 16 June 2008. Time evolution of aerosol particles size distribution in the size range 8-900 nm (a) and number concentration for diameters smaller than $20 \mathrm{~nm}$ as recorded by the SMPS (b), atmospheric ions size distribution in the size range $0.8-42 \mathrm{~nm}$ and number concentration for diameters between 2 and $20 \mathrm{~nm}$ for positive (c, d) and negative (e, f) ions measured with the AIS. Time of the day in UTC.

(local) conditions often occurring during the cold season (low temperature). High wind speeds lead to the dilution of atmospheric ions and enhance advection, leading to low ion concentration values. For wind velocities greater than $10 \mathrm{~m} \mathrm{~s}^{-1}$ no enhanced concentrations were found and as the wind speed increases ion number concentrations are below $1000 \mathrm{~cm}^{-3}$ with an average concentration of ca. $500 \mathrm{~cm}^{-3}$ (Fig. 3b). No statistically significant correlation was found for linear regression between ions of both polarities and $W_{s}$.

Even if diurnal patterns of ion concentrations could be explained on the diurnal patterns of ozone and BC, no statistically significant correlation was found when both ion polarities were plotted versus ozone and BC.

To explore the dependence of air ions in the size range 0.8 $42 \mathrm{~nm}$ on preexisting aerosol concentrations, we investigated their variability with respect to CS and CoagS. Ion concentrations were found to be anti-correlated with CS and CoagS for both negatively and positively charged particles (not shown); however, with poor correlations, for positive ions $R^{2}$ was 0.15 and 0.16 for CS and CoagS while for negative was 0.06 for both sinks.

\subsection{New particle formation at Finokalia}

During the measurement period, several new particle formation events were recorded. Details about the frequency of occurrence, formation rates, growth rates and condensational sinks of these events can be found in Manninen et al. (2010). In order to identify a new particle formation event, the event should have been apparent in SMPS data and ful- fil the criteria given by Birmili et al. (2003), so that plateau concentration of particles with diameter smaller than $20 \mathrm{~nm}$ was greater than $1000 \mathrm{~cm}^{-3}$ (criterion adjusted to detection limit of the SMPS we used), time for that concentration to increase was less than $4 \mathrm{~h}$, time to decline was less than $7 \mathrm{~h}$ and the fraction to the total particle concentration was greater than 0.15. In those cases that no concurrent SMPS data were available, criteria by Hirsikko at al. (2007) were used so that the formation event continued for several hours, the growth of new particles was evident in the size distribution data and the particles grew from cluster sizes up to the upper detection limit of AIS $(42 \mathrm{~nm})$.There were 53 nucleation events recorded during day-time. Common observation for all the events was that the initial nucleation evident in AIS data were then followed by condensational growth of the new particles to larger diameters, and the subsequent recording of the event by the SMPS system. In the morning of 16 June 2008 a typical nucleation event was recorded both by the AIS and SMPS (Fig. 4). It is worth noticing that nucleation is more pronounced for negatively charged ions than for positive ions. This was typical throughout the measurement period at Finokalia, nucleation of negatively charged particles is favored, a result which is in line with previous observations (Hirsikko et al., 2011). New particle formation was found to be more frequent in winter than in summer at Finokalia (Manninen et al., 2010).

Prior to or after the initiation of some day-time nucleation events it was evident that a process of enhanced ion concentrations was taking place at night. When looking at the size range $1.25-1.66 \mathrm{~nm}$, the size class representing the upper 

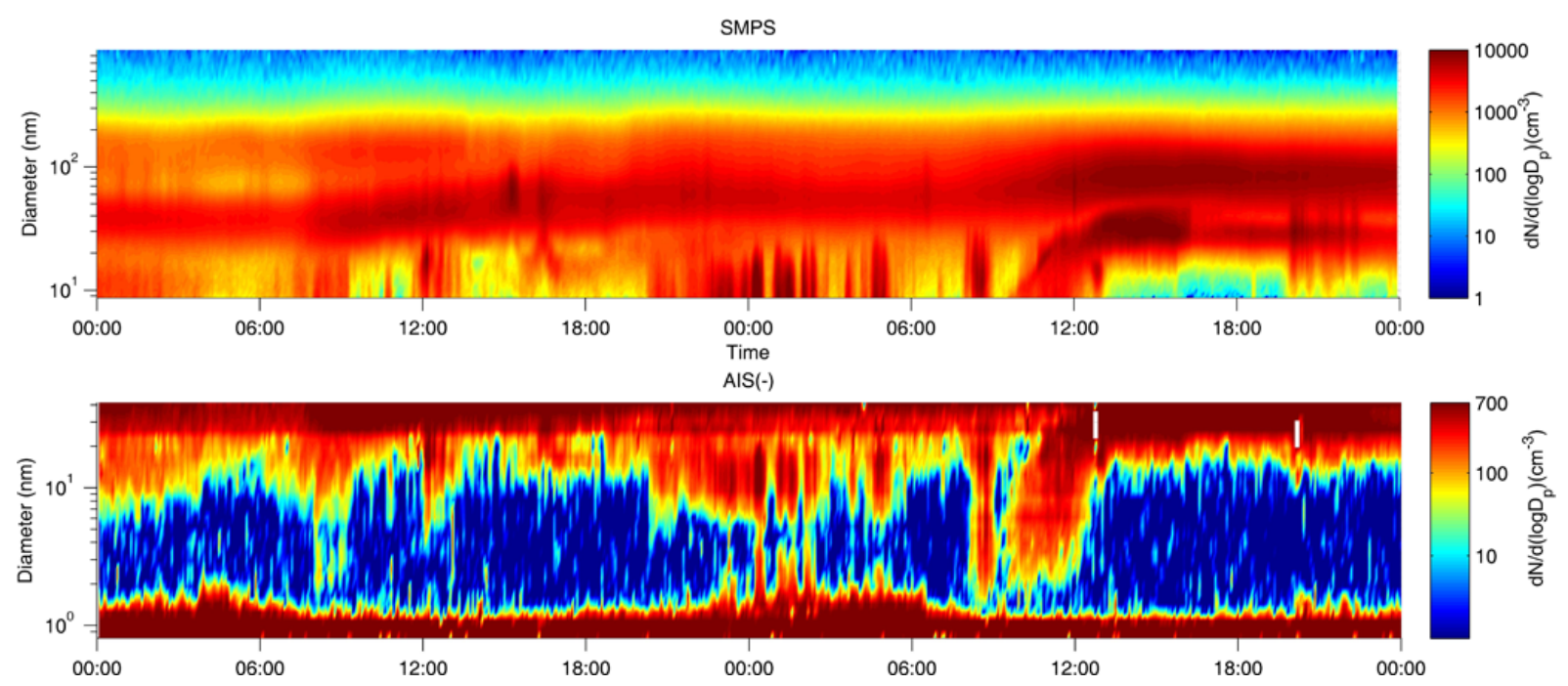

Fig. 5. Aerosol particles size distribution in the size range $8-900 \mathrm{~nm}$ (upper panel) and atmospheric ions size distribution in the size range 0.8-42 nm (lower panel) for the period 6-7 October 2008. New particle formation observed on 7 October as recorded by SMPS and AIS for negative polarity. The night before, new ions were formed and grew sufficiently to be recorded by the SMPS. Time of the day in UTC.

limit of the preexisting cluster ion pool, an apparent growth is evident accompanied by simultaneous increase of the ion concentration. In some cases subsequent growth to larger diameters was observed so that the event was captured by the SMPS as well (Fig. 5). The observation of a night-time increase in ion concentrations prior to a day-time nucleation event could theoretically be the first step of the two-step nucleation process proposed by Kulmala et al. (2000): at first the ion-induced formation of a cluster occurs followed by the subsequent growth when enough available vapours later on due to photochemical processes exist. Due to the scarcity of such observations especially for the MBL, no references exist so far, we will next focus on the characteristics governing such phenomena.

\subsection{Enhanced ion concentrations during the night at Finokalia}

Henceforth we will describe an enhanced ion concentration event as an event which initiates after sunset when solar irradiance is practically zero. In order to identify such an event, the variation of the ion number concentration in the $1.25-1.66 \mathrm{~nm}$ size bin was used, provided that an apparent growth of cluster ions to larger diameters than the upper limit of the preexisting ion pool is evident. The identification of such growth was made with the visual inspection of the contour plots of AIS data. An event was defined as an increase of ion concentration in the size range $1.25-1.66 \mathrm{~nm}$ of over $50 \mathrm{~cm}^{-3}$ and over one standard deviation from the day's median concentration, to provide that preexisting concentrations remained low. During the measurement period 39 events were recorded. Only for three of the cases there was enough growth so that there was evidence of these events in simultaneous measurements in the $8-900 \mathrm{~nm}$ size range performed with the SMPS (Fig. 5). Similar observations have been made by Junninen et al. (2008). During all of the recorded events, a clear lift above the cluster mode in the contour plot was observed simultaneously with an increase in $1.25-1.66 \mathrm{~nm}$ cluster number concentration.

For the night-time events observed, $28 \%$ of them were followed by a day-time nucleation event and $18 \%$ of the cases were observed after a day-time nucleation event, so that for almost half of the cases, these two features of air ions are observed in consecutive days. As mentioned already, these night-time events were evident for the negatively charged ions but not all of the events had correspondence in the positive ions, only 21 of them did. However, all the events for the positive polarity were observed for the negative polarity too.

The available measurement days were classified in event and non-event days. The fraction of event days was found to be $12.3 \%$ for negative and $6.7 \%$ for positive ions. Looking at the annual variation of the ratio some interesting features were revealed (Fig. 6). High concentration events for negative atmospheric ions at night were more frequent in April and November while from July to September no events were observed. For positive ions the trend was the same; however, the maximum observed for November was much weaker.

We then refined our analysis of the effect of various atmospheric parameters on night-time concentrations of 1.25$1.66 \mathrm{~nm}$ clusters. As for total ions (Fig. 3a), for temperatures higher than $20^{\circ} \mathrm{C}$ no cases of elevated concentration of ion clusters were found. As reported in earlier work for other environments (Curtius et al., 2006; Yu, 2010), low temperatures favor enhanced ion concentrations at Finokalia as well. During summer at Finokalia, temperatures remain well above this threshold. However, for the cluster ions no 


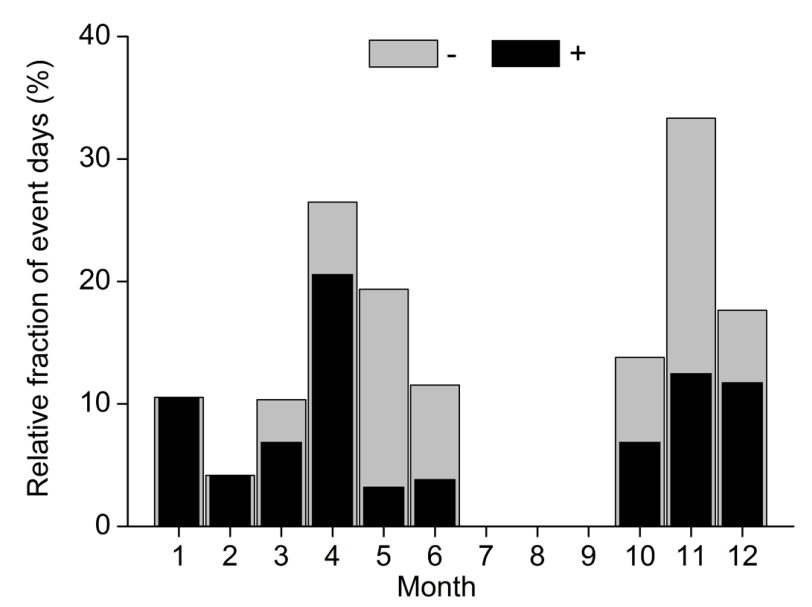

Fig. 6. Monthly relative fraction of night-time enhanced ion concentrations event days for negative (grey bars) and positive (black bars) ions.

correlation was found and $R^{2}$ for linear regression was below 0.03 for both polarities. High wind speeds lead to the dilution of atmospheric ions and enhance advection leading to low ion concentration values, $W_{s}$ greater than $10 \mathrm{~m} \mathrm{~s}^{-1}$ results in very low cluster ion concentrations. It was found that ambient RH can be important. High concentrations are found for $\mathrm{RH} \sim 100 \%$ probably, implying rain associated air ions (Hirsikko et al., 2007; Tammet et al., 2009). No significant correlation was observed for $\mathrm{RH}$ and $W_{s}$, correlation coefficients were nearly zero for both parameters.

With respect to ozone and for the cluster size ion concentrations, correlation coefficients were below 0.02 for both polarities. It was found that the $1.25-1.66 \mathrm{~nm}$ ion concentrations were highly anti-correlated on BC levels. For all the measurements a statistically significant correlation was observed, and exponential fit resulted in $R^{2}$ of 0.26 for positive and 0.32 for negative charges as indicated in Fig. 7 ( $n=80000, a=0.05$ for both Fig. $7 \mathrm{a}$ and $\mathrm{b}$ ). Ion concentrations can be dependent on BC levels for two reasons. First, in the remote pristine environment of Finokalia there are hardly any $\mathrm{BC}$ local sources and therefore enhanced BC concentrations indicate long range transport of air masses from major pollution and biomass burning sources. These sources can be found mainly in continental Europe, and when air masses of such origin are prevailing, local sources over the island of Crete that are, as explained later, the major ion sources suppressed (Sciare et al., 2008). Second, due to their long range transport origin, $\mathrm{BC}$ particles can be considered as good indicators of accumulation mode particles. As shown in Fig. 7c, there is a statistical significant correlation between $\mathrm{BC}$ concentration and coagulation sink $\left(R^{2}=0.33\right.$, $n=54000, a=0.05$ ), resulting from the contribution of BC particles to total available surface of atmospheric aerosols.

Thus, it was expected that a similar trend would be also observed for the dependence of ion concentrations on CoagS and, as can be seen in Fig. 8, this exponential anti-correlation of cluster ions on preexisting aerosol particles was even more pronounced. Not only for the night-time observations but for the total of the measurement period, ion clusters were exponentially anti-correlated with CoagS. Once again, negative ions were more sensitive to the presence of aerosol particles and had better correlation. For all measurements and only for night-time measurements, $R^{2}$ was 0.32 and 0.33 for positive charges and 0.46 and 0.42 for the negative, respectively. Calculating median night-time ion concentrations per $10^{-4} \mathrm{~s}^{-1}$ intervals of CoagS and then fitting median values, the fitting results were excellent, $\mathrm{R}^{2}$ values were 0.96 and 0.98 for positive and negative polarity, respectively (Fig. 8c, f). An extreme case of CoagS and negative ions anti-correlation is presented in Fig. 9 where it can be noticed that the rapid drop in CoagS is directly accompanied by an increase of $1.25-$ $1.66 \mathrm{~nm}$ negative clusters concentration and the observation of a night-time event.

We also studied the dependence of night-time increased ion concentrations on the origin of air masses, since from the previous analysis it was obvious that the concentration of small air ions is strongly dependent on atmospheric composition, which in turn significantly depends on air mass history at Finokalia. For this reason we used trajectory analysis using the HYSPLIT model (Hybrid Single-Particle Lagrangian Integrated Trajectory Model, Draxler and Hess, 1998) at the altitude of $1000 \mathrm{~m}$ which is considered to be representative of the boundary layer at Finokalia (Kalivitis et al., 2007). Five days back-trajectory analysis revealed that almost $77 \%$ of the events observed took place when air masses originated from the wide W/S sector (Fig. 10). The results showed intrusion of air masses from higher altitudes for the majority of the events and thus influence of cleaner air masses. The majority of the events were observed when air masses originated from the W/SW and thus spent time over the island of Crete.

The relationship between the concentration of 1.25$1.66 \mathrm{~nm}$ negative clusters and the wind direction was further investigated. The results are presented in Fig. 11 as a polar diagram centered on the Finokalia station. Indeed, the greatest variability and the highest concentrations of negative ion clusters are observed when air masses come from the inland of Crete and thus have been in contact with solid ground; except of two cases observed at 355 and $55^{\circ}$ for which no clear explanation can be given. As night-time events were found to coincide with low $\mathrm{BC}$ values, thus biogenic rather than anthropogenic sources could account for their presence. As reported by Tunved et al. (2006), the sources of nucleating and condensing species are stronger over land than over the marine environment. In addition to the origin of the air masses that are from the wide W/SW and descend from higher altitudes and hence are considered as clean air masses (Kalivitis et al., 2008; Stock et al., 2011), the conditions for the enhancement of cluster ion concentrations are met. 


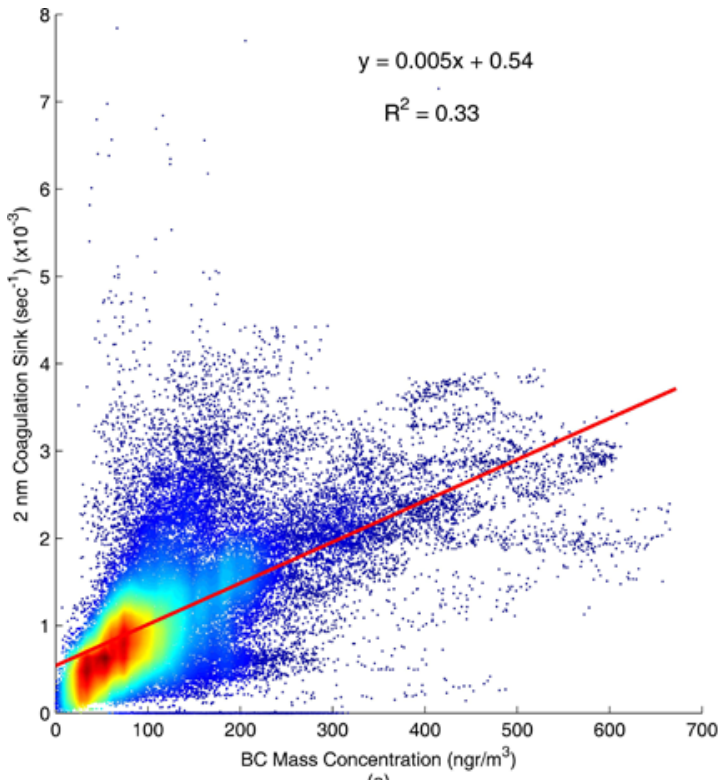

(a)

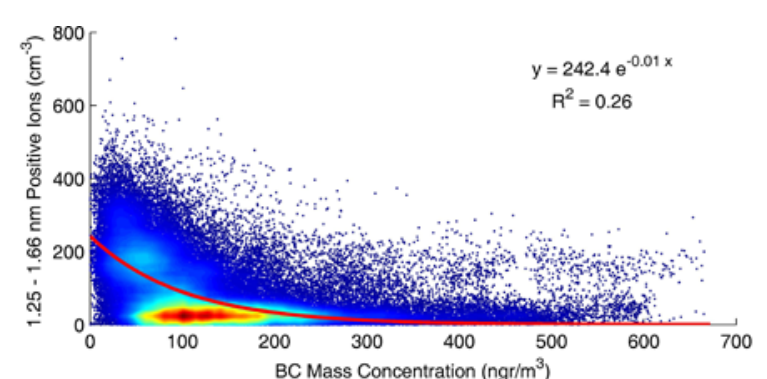

(b)

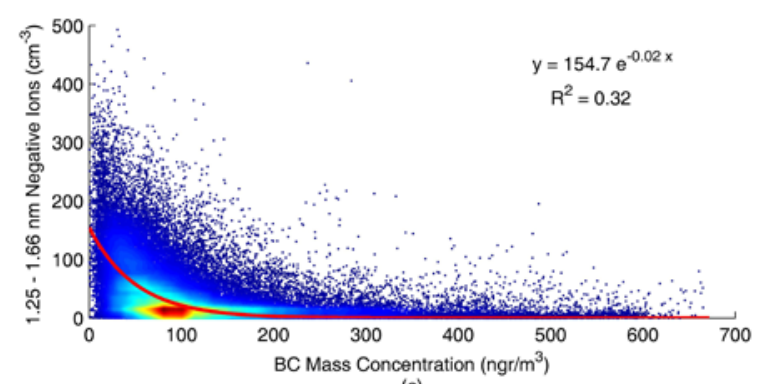

(c)

Fig. 7. 2 nm Coagulation Sink variability versus BC mass concentration (a) and variability of atmospheric cluster concentrations at the size range 1.25-1.66 nm depending on BC mass concentration for positive (b) and negative charges (c), respectively.
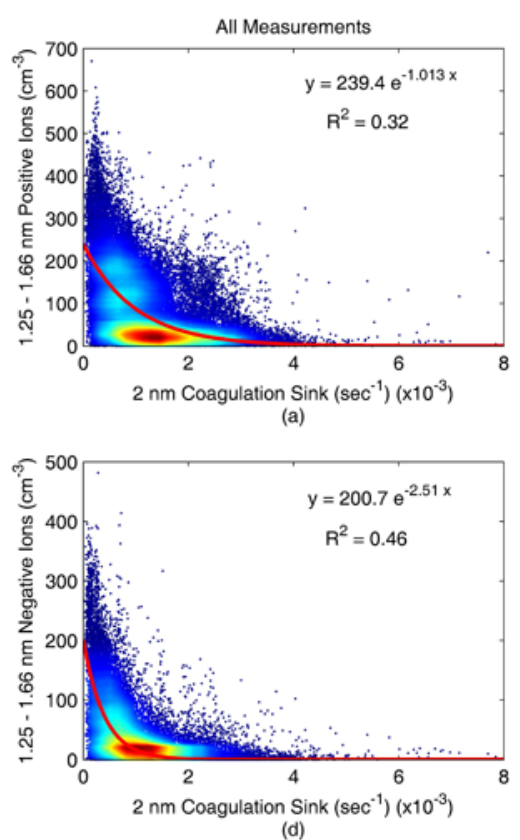

(d)

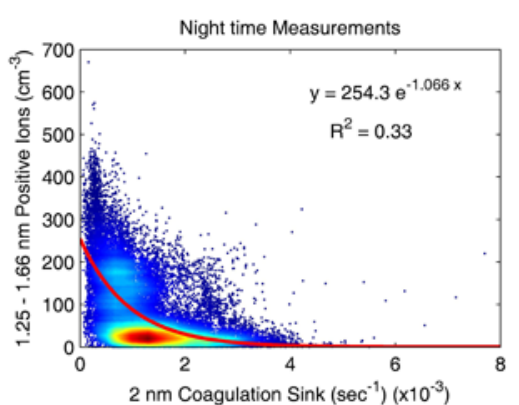

(b)

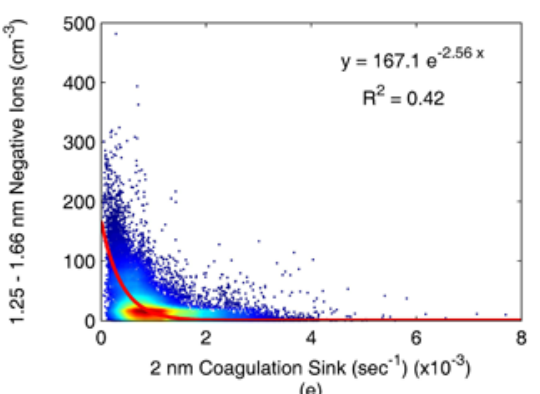

(e)

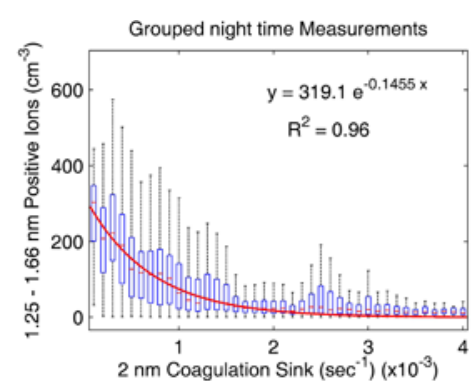

(c)

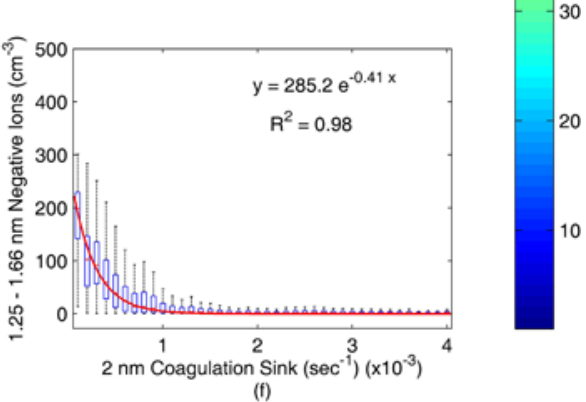

Fig. 8. Variability of atmospheric cluster concentrations at the size range $1.25-1.66 \mathrm{~nm}$ depending on CoagS for $2 \mathrm{~nm}$ particles and exponential fit lines for both polarities for all measurements $(\mathbf{a}, \mathbf{d})$, night-time measurements $(\mathbf{b}, \mathbf{e})$ and grouped night-time measurements per $10^{-4} \mathrm{~s}^{-1}$ of CoagS $(\mathbf{c}, \mathbf{f})$.

\section{Conclusions}

In the frame of the EUCAARI project, atmospheric ions measurements took place at the research station of Finokalia during the period April 2008-April 2009. On the course of a year, the concentration of both positively and negatively charged ions were observed to be at their lowest level during summer. The maximum values for the positive air ions were observed in winter and in March for the negative ones with secondary maxima in June and November. Negative ions had slightly higher concentrations than positive ions on average. Atmospheric ions at Finokalia had a clear diurnal 

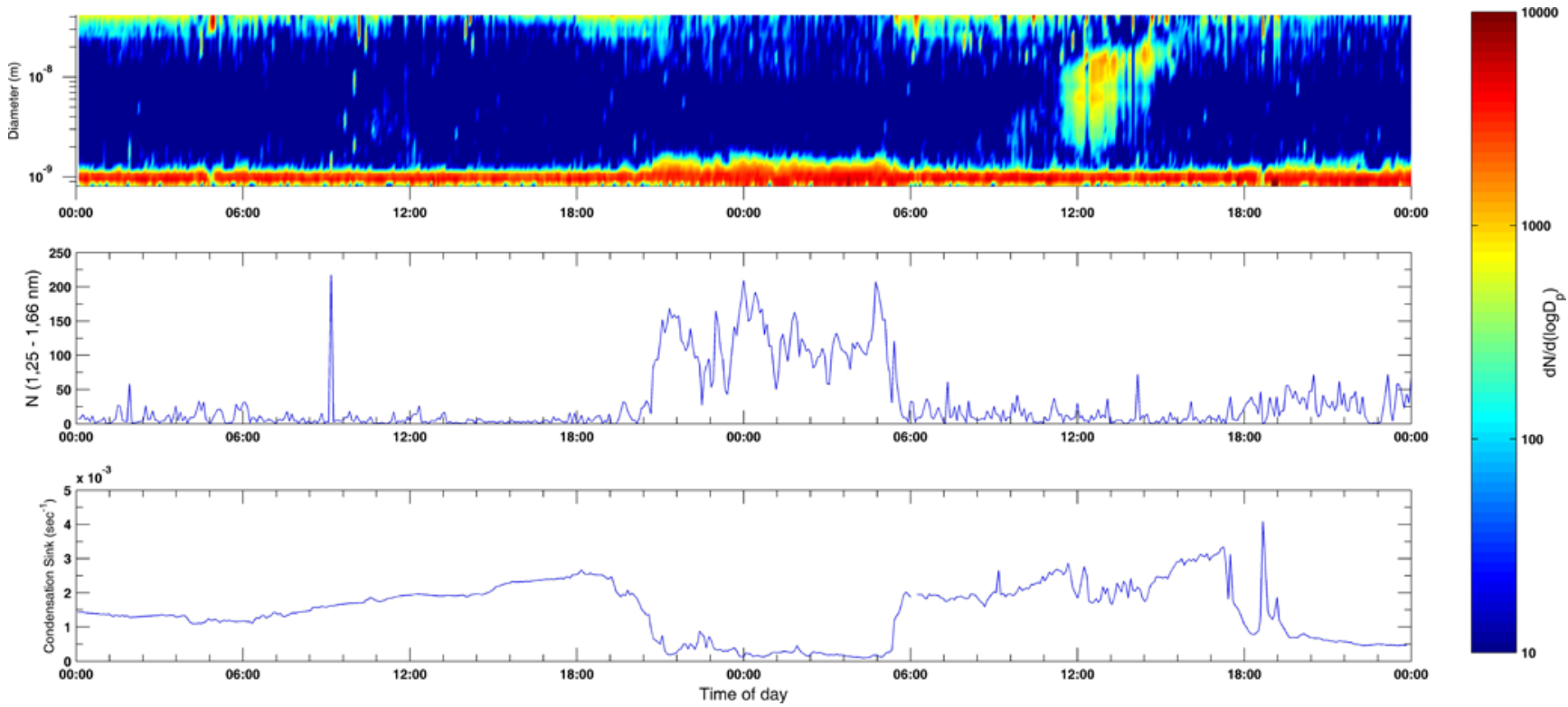

Fig. 9. Night-time enhanced ion concentration event observed on 29-30 March 2009 demonstrating a clear case of anti-correlation of small ion cluster concentrations with CoagS. Upper panel: negative ion number size distribution. Middle panel: negative ion number concentration in the size range $1.25-1.66 \mathrm{~nm}$. Lower panel: $2 \mathrm{~nm}$ CoagS. Time of the day in UTC.
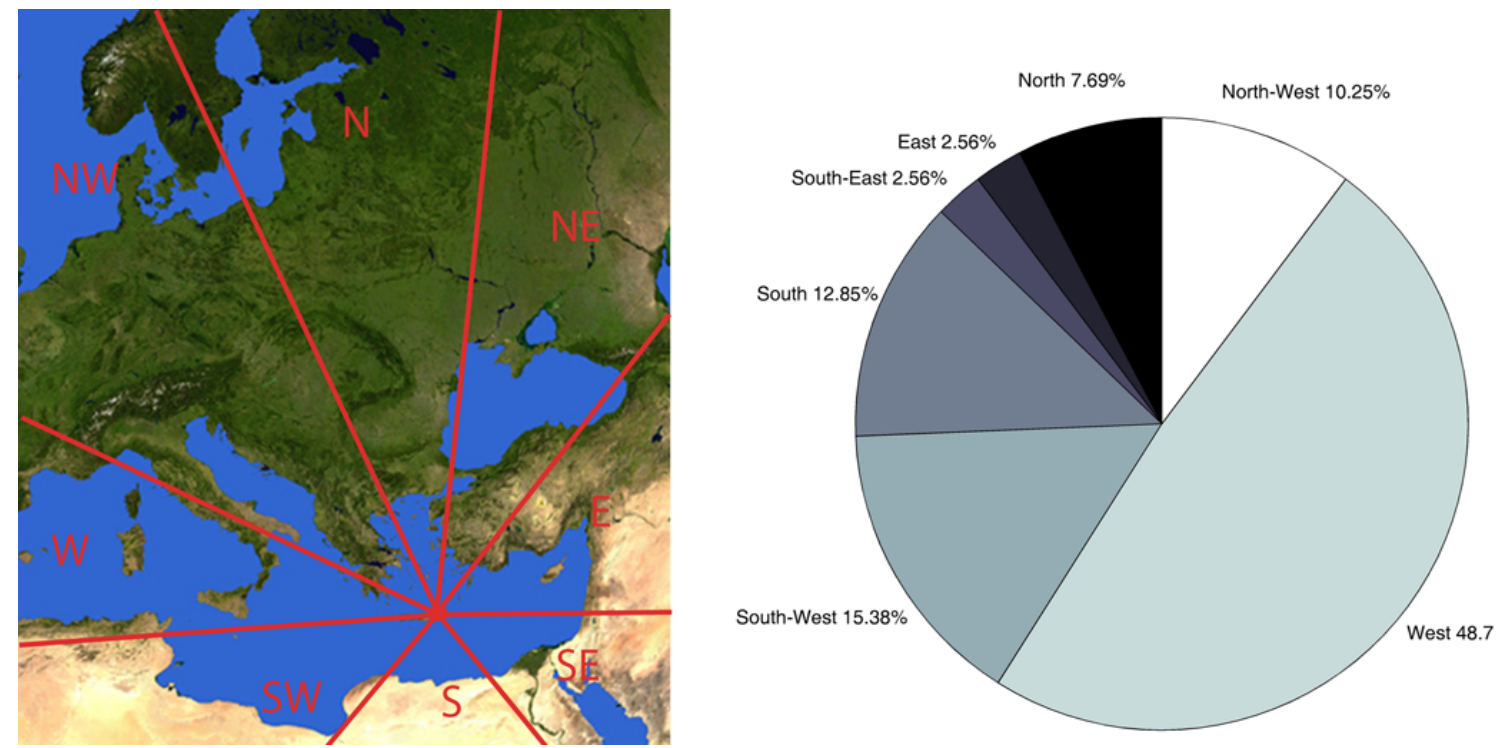

Fig. 10. Distribution of air masses origin at $1000 \mathrm{~m}$ (5 days back trajectory) arriving at Finokalia during night-time enhanced ion concentrations events.

cycle with higher values at night. It was found that the clusters and small air ions are sensitive to the presence of $\mathrm{BC}$ and ozone in the atmosphere. Anti-correlation was also observed with temperature while it was observed that high wind velocity restricted the abundance of ions. It was found that the ion concentrations were anti-correlated with CS and CoagS by aerosol particles.

During the period of the measurements, 53 day-time nucleation events were observed. Additionally, 39 events of en- hanced ion concentration were recorded during night-time. A very interesting observation was that almost half of the nighttime enhanced concentration events were observed prior or after day-time nucleation events. Night-time enhanced concentration events were found to be more frequent during spring and autumn, peaking in April and November while no events were observed from July to September. It was found that the $1.25-1.66 \mathrm{~nm}$ cluster ions are even more sensitive to the presence of preexisting aerosols. A strong exponential 


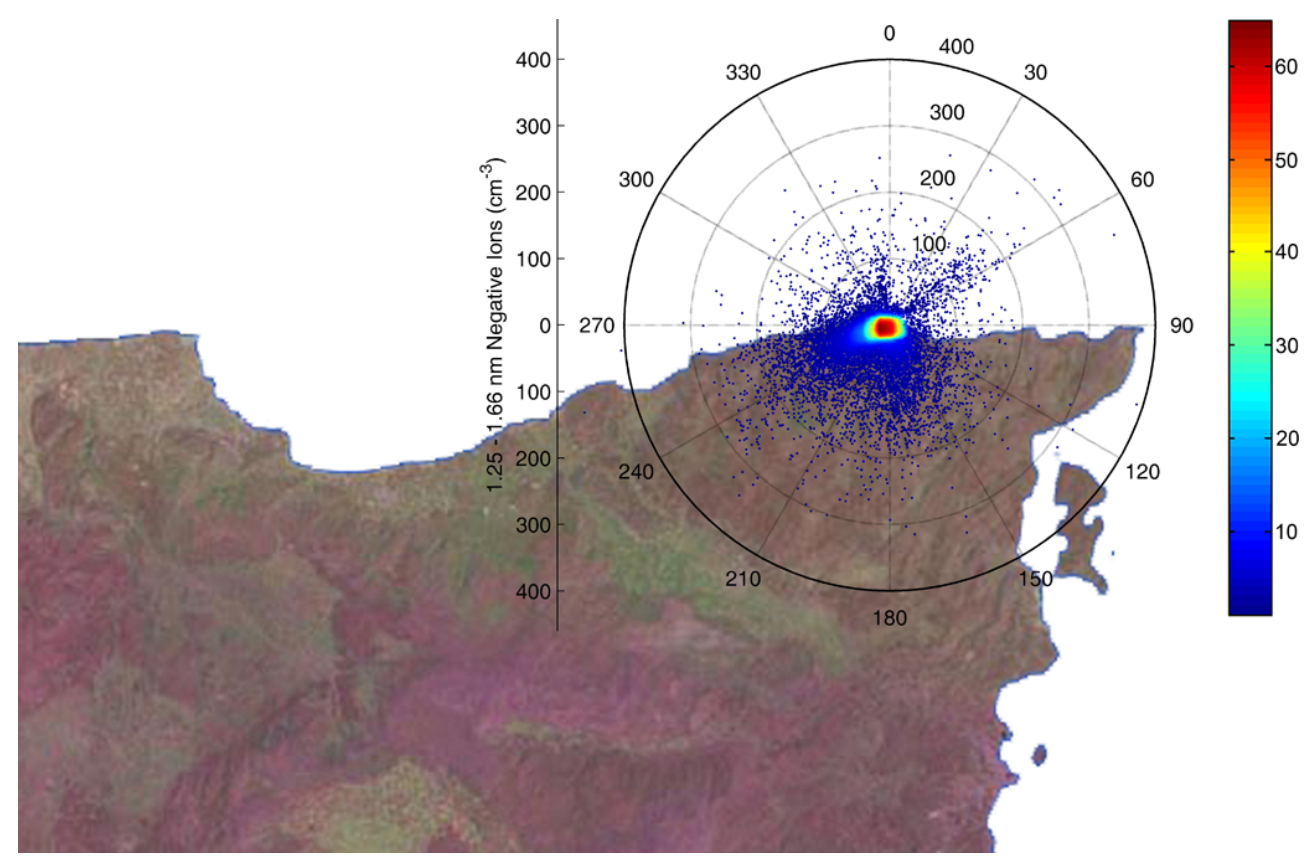

Fig. 11. Dependence of negatively charged atmospheric cluster concentrations at the size range $1.25-1.66 \mathrm{~nm}$ on the wind direction.

anti-correlation was found between cluster ion concentrations and CoagS. Through analyzing air mass history, we concluded that a night-time event is more likely to take place when the air masses had spent some time over the land and they originated from the clean wide W/SW sector. While examining air ion concentrations with regard to wind direction, it became obvious that the greatest variability was observed when air was blowing from inland. In general, low preexisting aerosol concentrations and a passage overland are necessary conditions to observe high concentrations of ion clusters at Finokalia.

Acknowledgements. The data evaluation for this paper was conducted within the European Integrated project on Aerosol Cloud Climate and Air Quality Interactions (EUCAARI), coordinated by M. Kulmala. The authors would like to thank the editor and the 3 anonymous reviewers for their helpful comments, which help us to improve the submitted manuscript. They also acknowledge the NOAA Air Resources Laboratory (ARL) for the provision of the back trajectory data (http://www.arl.noaa.gov/ready/hysplit4.html).

Edited by: A. Wiedensohler

\section{References}

Asmi, E., Sipilä, M., Manninen, H. E., Vanhanen, J., Lehtipalo, K., Gagné, S., Neitola, K., Mirme, A., Mirme, S., Tamm, E., Uin, J., Komsaare, K., Attoui, M., and Kulmala, M.: Results of the first air ion spectrometer calibration and intercomparison workshop, Atmos. Chem. Phys., 9, 141-154, doi:10.5194/acp-9-141-2009, 2009.
Bazilevskaya, G. A., Usoskin, I. G., Flückiger, E. O., Harrison, R. G., Desorgher, L., Bütikofer, R., Krainev, M. B., Makhmutov, V. S., Stozhkov, Y. I., Svirzhevskaya, A. K., Svirzhevsky, N. S., and Kovaltsov, G. A.: Cosmic Ray Induced Ion Production in the Atmosphere, Space Sci. Rev., 137, 149-173, 2008.

Birmili, W., Stratmann, F., and Wiedensohler, A.: Design of a DMA-based size spectrometer for a large particle size range and stable operation, J. Aerosol Sci., 30, 549-553, 1999.

Birmili, W., Berresheim, H., Plass-Dülmer, C., Elste, T., Gilge, S., Wiedensohler, A., and Uhrner, U.: The Hohenpeissenberg aerosol formation experiment (HAFEX): a longterm study including size-resolved aerosol, $\mathrm{H}_{2} \mathrm{SO}_{4}, \mathrm{OH}$, and monoterpenes measurements, Atmos. Chem. Phys., 3, 361-376, doi:10.5194/acp-3-361-2003, 2003.

Curtius, J., Lovejoy, E. R., and Froyd, K. D.: Atmospheric ioninduced aerosol nucleation, Space Sci. Rev., 125, 159-167, 2006.

Draxler, R. R. and Hess, G. D.: An overview of the HYSPLIT_4 modeling system for trajectories, dispersion and deposition, Aust. Meteorol. Mag., 47, 295-308, 1998.

Eichmeier, J. A. and von Berckheim, C. Ph.: Measurement of Atmospheric-Electric Field Strength and Air-Ion Concentration at Varying Distances From the Coast With a Mobile Measuring Station, Arch. Meteor. Geophy., 28, 107-109, 1979.

Gagné, S., Laakso, L., Petaja, T., Kerminen, V. M., Kulmala, M.: Analysis of one year of Ion-DMPS data from the SMEAR II station, Finland, Tellus B, 60, 318-329, 2008.

Gagné, S., Lehtipalo, K., Manninen, H. E., Nieminen, T., Schobesberger, S., Franchin, A., Yli-Juuti, T., Boulon, J., Sonntag, A., Mirme, S., Mirme, A., Hõrrak, U., Petäjä, T., Asmi, E., and Kulmala, M.: Intercomparison of air ion spectrometers: an evaluation of results in varying conditions, Atmos. Meas. Tech., 4, 805-822, doi:10.5194/amt-4-805-2011, 2011. 
Hirsikko, A., Bergman, T., Laakso, L., Dal Maso, M., Riipinen, I., Hõrrak, U., and Kulmala, M.: Identification and classification of the formation of intermediate ions measured in boreal forest, Atmos. Chem. Phys., 7, 201-210, doi:10.5194/acp-7-201-2007, 2007.

Hirsikko, A., Nieminen, T., Gagné, S., Lehtipalo, K., Manninen, H. E., Ehn, M., Hõrrak, U., Kerminen, V.-M., Laakso, L., McMurry, P. H., Mirme, A., Mirme, S., Petäjä, T., Tammet, H., Vakkari, V., Vana, M., and Kulmala, M.: Atmospheric ions and nucleation: a review of observations, Atmos. Chem. Phys., 11, 767798, doi:10.5194/acp-11-767-2011, 2011.

Israël, H.: Atmospheric Electricity, Israel Program for Scientific Translations, Jerusalem, 1, 317 pp., 1970.

Junninen, H., Hulkkonen, M., Riipinen, I., Nieminen, T., Hirsikko, A., Suni, T., Boy, M., Lee, S.-H., Vana, M., Tammet, H., Kerminen, V.-M., and Kulmala, M.: Observations on nocturnal growth of atmospheric clusters, Tellus B, 60, 365-371, doi:10.1111/j.1600-0889.2008.00356.x, 2008.

Kalivitis, N., Gerasopoulos, E., Vrekoussis, M., Kouvarakis, G., Kubilay, N., Hatzianastassiou, N., Vardavas, I., and Mihalopoulos, N.: Dust transport over the eastern Mediterranean derived from Total Ozone Mapping Spectrometer, Aerosol Robotic Network, and surface measurements, J. Geophys. Res.-Atmos., 112, D03202, doi:10.1029/2006JD007510, 2007.

Kalivitis, N., Birmili, W., Stock, M., Wehner, B., Massling, A., Wiedensohler, A., Gerasopoulos, E., and Mihalopoulos, N.: Particle size distributions in the Eastern Mediterranean troposphere, Atmos. Chem. Phys., 8, 6729-6738, doi:10.5194/acp-8-67292008, 2008.

Kerminen, V.-M., Petäjä, T., Manninen, H. E., Paasonen, P., Nieminen, T., Sipilä, M., Junninen, H., Ehn, M., Gagné, S., Laakso, L., Riipinen, I., Vehkamäki, H., Kurten, T., Ortega, I. K., Dal Maso, M., Brus, D., Hyvärinen, A., Lihavainen, H., Leppä, J., Lehtinen, K. E. J., Mirme, A., Mirme, S., Hõrrak, U., Berndt, T., Stratmann, F., Birmili, W., Wiedensohler, A., Metzger, A., Dommen, J., Baltensperger, U., Kiendler-Scharr, A., Mentel, T. F., Wildt, J., Winkler, P. M., Wagner, P. E., Petzold, A., Minikin, A., Plass-Dülmer, C., Pöschl, U., Laaksonen, A., and Kulmala, M.: Atmospheric nucleation: highlights of the EUCAARI project and future directions, Atmos. Chem. Phys., 10, 10829-10848, doi:10.5194/acp-10-10829-2010, 2010.

Kouvarakis, G., Tsigaridis, K., Kanakidou, M., and Mihalopoulos, N.: Temporal variations of surface regional background ozone over Crete Island in the southeast Mediterranean, J. Geophys. Res.-Atmos., 105, 4399-4407, 2000.

Kulmala, M. and Tammet, H.: Finnish-Estonian air ion and aerosol workshops, Boreal Environ. Res., 12, 237-245, 2007.

Kulmala, M., Pirjola, U., and Mäkelä, J.: Stable sulphate clusters as a source of new atmospheric particles, Nature, 404, 66-69, 2000.

Kulmala, M., Dal Maso, M., Mäkelä, J. M., Pirjola, L., Väkevä, M., Aalto, P., Miikkulainen, P., Hämeri, K., and O'Dowd, C.: On the formation, growth and composition of nucleation mode particles, Tellus B, 53, 479-490, 2001.

Kulmala, M., Riipinen, I., Sipila, M., Manninen, H. E., Petaja, T., Junninen, H., Dal Maso, M., Mordas, G., Mirme, A., Vana, M., Hirsikko, A., Laakso, L., Harrison, R. M., Hanson, I., Leung, C., Lehtinen, K. E. J., and Kerminen, V. M.: Toward direct measurement of atmospheric nucleation, Science, 318, 89-92, 2007.
Kulmala, M., Asmi, A., Lappalainen, H. K., Carslaw, K. S., Pöschl, U., Baltensperger, U., Hov, Ø., Brenquier, J.-L., Pandis, S. N., Facchini, M. C., Hansson, H.-C., Wiedensohler, A., and O'Dowd, C. D.: Introduction: European Integrated Project on Aerosol Cloud Climate and Air Quality interactions (EUCAARI) - integrating aerosol research from nano to global scales, Atmos. Chem. Phys., 9, 2825-2841, doi:10.5194/acp-9-2825-2009, 2009.

Laakso, L., Petäjä, T., Lehtinen, K. E. J., Kulmala, M., Paatero, J., Hõrrak, U., Tammet, H., and Joutsensaari, J.: Ion production rate in a boreal forest based on ion, particle and radiation measurements, Atmos. Chem. Phys., 4, 1933-1943, doi:10.5194/acp-41933-2004, 2004.

Lehtipalo, K., Sipilä, M., Junninen, H., Ehn, M., Berndt, T., Kajos, M. K., Worsnop, D. R., Petäjä, T., and Kulmala, M.: Observations of nano-CN in the nocturnal boreal forest, Aerosol Sci. Technol., 45, 499-509, 2011.

Lelieveld, J., Berresheim, H., Borrmann, S., Crutzen, P., Dentener, F., Fischer, H., Feichter, J., Flatau, P., Heland, J., Holzinger, R., Korrmann, R., Lawrence, M., Levin, Z., Markowicz, K., Mihalopoulos, N., Minikin, A., Ramanathan, V., de Reus, M., Roelofs, G., Scheeren, H., Sciare, J., Schlager, H., Schultz, M., Siegmund, P., Steil, B., Stephanou, E., Stier, P., Traub, M., Warneke, C., Williams, J., and Ziereis, H.: Global air pollution crossroads over the Mediterranean, Science, 298, 794-799, 2002.

Manninen, H. E., Petäjä, T., Asmi, E., Riipinen, I., Nieminen, T., Mikkilä, J., Hõrrak, U., Mirme, A., Mirme, S., Laakso, L., Kerminen, V.-M., and Kulmala, M.: Long-term field measurements of charged and neutral clusters using Neutral cluster and Air Ion Spectrometer (NAIS), Boreal Environ. Res., 14, 591-605, 2009.

Manninen, H. E., Nieminen, T., Asmi, E., Gagné, S., Häkkinen, S., Lehtipalo, K., Aalto, P., Vana, M., Mirme, A., Mirme, S., Hõrrak, U., Plass-Dülmer, C., Stange, G., Kiss, G., Hoffer, A., Törő, N., Moerman, M., Henzing, B., de Leeuw, G., Brinkenberg, M., Kouvarakis, G. N., Bougiatioti, A., Mihalopoulos, N., O'Dowd, C., Ceburnis, D., Arneth, A., Svenningsson, B., Swietlicki, E., Tarozzi, L., Decesari, S., Facchini, M. C., Birmili, W., Sonntag, A., Wiedensohler, A., Boulon, J., Sellegri, K., Laj, P., Gysel, M., Bukowiecki, N., Weingartner, E., Wehrle, G., Laaksonen, A., Hamed, A., Joutsensaari, J., Petäjä, T., Kerminen, V.-M., and Kulmala, M.: EUCAARI ion spectrometer measurements at 12 European sites - analysis of new particle formation events, Atmos. Chem. Phys., 10, 7907-7927, doi:10.5194/acp-10-79072010, 2010.

Mihalopoulos, N., Stephanou, E., Kanakidou, M., Pilitsidis, S., and Bousquet, P.: Tropospheric aerosol ionic composition in the Eastern Mediterranean region, Tellus B, 49, 314-326, 1997.

Mirme, A., Tamm, E., Mordas, G., Vana, M., Uin, J., Mirme, S., Bernotas, T., Laakso, L., Hirsikko, A., and Kulmala, M.: A widerange multi-channel air ion spectrometer, Boreal Environ. Res., 12, 247-264, 2007.

Retalis, A., Nastos, P., and Retalis, D.: Study of small ions concentration in the air above Athens, Greece, Atmos. Res., 91, 219228, 2009.

Retalis, D. A.: On the Relationship Between Small Atmospheric Ions Concentration and (1) Smoke, (2) Sulfur Dioxide and (3) Wind Speed, Pure Appl. Geophys., 115, 575-581, 1977.

Sciare, J., Oikonomou, K., Favez, O., Liakakou, E., Markaki, Z., Cachier, H., and Mihalopoulos, N.: Long-term measurements of 
carbonaceous aerosols in the Eastern Mediterranean: evidence of long-range transport of biomass burning, Atmos. Chem. Phys., 8, 5551-5563, doi:10.5194/acp-8-5551-2008, 2008.

Siingh, D., Pawar, S. D., Gopalakrishnan, V., and Kamra, A. K.: Measurements of the Ion Concentrations and Conductivity over the Arabian Sea during the ARMEX, J. Geophys. Res., 110, D18207, doi:10.1029/2005JD005765, 2005.

Stock, M., Cheng, Y. F., Birmili, W., Massling, A., Wehner, B., Müller, T., Leinert, S., Kalivitis, N., Mihalopoulos, N., and Wiedensohler, A.: Hygroscopic properties of atmospheric aerosol particles over the Eastern Mediterranean: implications for regional direct radiative forcing under clean and polluted conditions, Atmos. Chem. Phys., 11, 4251-4271, doi:10.5194/acp-11-4251-2011, 2011.

Tammet, H., Hõrrak, U., and Kulmala, M.: Negatively charged nanoparticles produced by splashing of water, Atmos. Chem. Phys., 9, 357-367, doi:10.5194/acp-9-357-2009, 2009.

Tunved, P. Hansson, H.-C., Kerminen, V.-M., Ström, J., Dal Maso, M., Lihavainen, H., Viisanen, Y., Aalto, P. P., Komppula, M., and Kulmala, M.: High natural aerosol loading over Boreal forests, Science, 312, 261-263, 2006.
Vana, M., Ehn, M., Petäjä, T., Vuollekoski, H., Aalto, P., de Leeuw, G., Ceburnis, D., O'Dowd, C. D., and Kulmala, M.: Characteristic features of air ions at Mace Head on the west coast of Ireland, Atmos. Res., 90, 278-286, doi:10.1016/j.atmosres.2008.04.007, 2008.

Virkkula, A., Hirsikko, A., Vana, M., Aalto, P. P., Hillamo, R., and Kulmala, M.: Charged particle size distributions and analysis of particle formation events at the Finnish Antarctic research station Aboa, Boreal Environ. Res., 12, 397-408, 2007a.

Virkkula, A., Mäkelä, T., Hillamo, R., Yli-Tuomi, T., Hirsikko, A., Hämeri, K., and Koponen, I. K.: A simple procedure for correcting loading effects of aethalometer data, J. Air Waste Manage., 57, 1214-1222, 2007b.

Wilding, R. J. and Harrison, R. G.: Aerosol modulation of small ion growth in coastal air, Atmos. Environ., 39, 5876-5883, 2005.

Yu, F.: Ion-mediated nucleation in the atmosphere: Key controlling parameters, implications, and look-up table, J. Geophys. Res.Atmos., 115, D03206, doi:10.1029/2009JD012630, 2010. 